\title{
Symbolic Deixis in Persuasive Discourse: Review of Learning Media with Forensic Linguistic Perspective
}

\author{
Dwilaksana $^{3}$, Purwadi Wahyu Anggoro ${ }^{4}$ \\ ${ }^{1}$ Faculty of Teacher Training and Education, Universitas Muhammadiyah Surakarta \\ ${ }^{2}$ Faculty of Law, Universitas Muhammadiyah Surakarta \\ ${ }^{3}$ Postgraduate Program of Police Studies, Universitas Indonesia \\ ${ }^{4}$ Doctor of Law Program, Universitas Muhammadiyah Surakarta \\ *Corresponding author. Email: sw122@ums.ac.id
}

Sri Waljinah ${ }^{1 *}$, Khudzaifah Dimyati ${ }^{2}$, Harun Joko Prayitno ${ }^{1}$, Chryshnanda

\begin{abstract}
Persuasive speech becomes a strategy to attain certain goals and objectives in the communication process. The present study aims at revealing symbolic deixis in persuasive discourse on road signs/lane markings, specifically popular jargons as learning media based on the perspective of forensic linguistics. The method is qualitative descriptive based on library study of scientific books and journals, with main topics of symbolic deixis, persuasive discourse, and learning media. Data include the texts on selected road signs. Analytical technique is interpretations based on symbolic deixis in persuasive discourse. This study reveals that symbolic deixis on road signs is a trick to attract the attention of road users. The texts are persuasive discourse as a means to encourage road users to comply with traffic regulations. Symbolic deixis in persuasive discourse on road signs is a message to promote the safety of road users. Persuasive discourse on road signs can be employed as forensic linguistic-based learning media.
\end{abstract}

Keywords: Symbolic deixis, persuasive discourse, learning media, forensic linguistics

\section{INTRODUCTION}

Formal Deixis within a discourse is way of referring a specific nature by using a language that can only be interpreted according to the meaning referred to by the speaker and affected by the circumstance of conversation. In case one element of the meaning of a word or sentence alters due to a change in the context, the word or phrase has deixis meaning. The text on road signs has deixis meaning because it encloses a persuasive power directed to the road users so as they are interesting in paying attention and obeying the traffic regulations.

Road signs are written communication media aimed at road users to comply with traffic regulations. Yet most of them are deemed to be normative hence road users are less interested in noticing them. Therefore, there is a notion to package and modernize them in the form of markings with the latest jargons. It is particularly related to the technological advance that influences a shift in language use, especially the choice of terms in Indonesian legal field. Consequently, many linguists and law experts increasingly deepen their linguistics, both theory and practice, due to the importance of its functions as a communication medium [1]. Similarly, road sign as regulations are also conveyed to the public by using contemporary texts so as to attract and apply by various road users.
Deixis in the persuasive discourse on road signs is arranged using eye-catching words or phrase. The composition complies with the latest topics among people, i.e., chat, $L G B T$ and jomblo. The goal of this preference is to lure road users in reading and then obeying traffic regulations. Such regulations are linked to forensic linguistics as part of applied linguistics [2]. Therefore, the utilization of contemporary language on road signs is a sort of learning media with a forensic linguistic perspective as part of applied linguistics.

Discourse on road signs embodies symbolic deixis, which is optimized to persuade road users to stick to traffic regulations. Symbolic deixis in road signs is employed like billboard ads as an attempt to socialize traffic regulations. Billboard ads are media put on the roadside to promote a particular product by using advertising language to persuade and influence readers [3]. Similarly, road signs use such strategies hence they are noticeable so as to persuade and influence road users to comply with regulations.

Regarding symbolic deixis in persuasive discourse on road signs, several problems are formulated: What is the symbolic deixis in persuasive discourse on road signs? And how persuasive discourse on road signs is used as forensic linguistic-based learning media? The aims of this study are to reveal symbolic deixis in persuasive discourse on road signs, and describe persuasive discourse on road signs used as forensic linguistic-based learning media. 


\subsection{Related Work}

Previous studies have similar topic with the present study. One of them carried out by Wardani [4] about Bahasa Indonesia in the persuasive discourse of public appeal. It aims at investigating Bahasa Indonesia in the persuasive discourse of public appeal. Data were collected through observation, noting and recording methods. Analytical techniques were based on the channel and objective of communication. It concludes: (1) the persuasive discourse of public appeal consists of parts of body, without opening or closing; (2) the speech acts of the persuasive discourse of public appeal are in accordance with the formal structure of sentences and social goals; and (3) the manifestation of direct, indirect, conflictual, competitive, collaborative, and convivial speech acts.

Panggabean and Lestari [5] discussed the appraisal in evaluation of language as a forensic discourse scheme. It aimed at disclosing the evaluation of language on attitude, positioning, and graduation appraisal model. A qualitative descriptive approach was utilized by using the concordance and distribution analysis method with Simple Concordance Program (SCP) software. The results claim that: (1) the pattern of lexical appraisal use of negative attitude by the element of affection, appraisal, and appreciation; (2) patterns of lexical appraisal use of negative graduation dominated lexis metaphor in phenomena in public; and (3) Appraisal model of the texts in the articles is the attitude positioning graduation.

Awalludin [6] examined the effectiveness of decision making model in writing persuasive paragraphs. It aimed at revealing the differences between the pre- and postimplementation of decision making learning model, and the effectiveness of the model in the learning process. It employed experimental method in which data were obtained from the result of the test of writing persuasive paragraph while analysis was done by using statistical examination of $t$ test. The results include: (1) the average score of the initial test y was 61.29 and the final test was 77.76 , or there was an increase by 16.47 ; (2) the calculation obtained t ratio of 8.22 and t table of 2.02 at $5 \%$ significance level, or t ratio was higher than t table (8.22> 2.02); and (3) the decision making model is shown to be effective in learning how to write persuasive paragraph.

Basically, the present study has similarity with Wardhani [4] regarding the description of Bahasa Indonesia in the persuasive discourse of public appeal, Panggabean and Lestari [5] on the discourse of forensic perspective, and Awalludin [6] on persuasive discourse. However, some dissimilarities are apparent. The present study differs from Wardhani [4] on the discussion of the symbolic deixis in persuasive discourse, Panggabean and Lestari [5] on the association of persuasive discourse and forensic linguistics, and Awalludin [6] on the discussion of persuasive discourse related to symbolic deixis. The object of the present study is also distinctive to previous studies, namely the persuasive discourse in current slangs or jargons on road signs.

\subsection{Methodology}

The present study is a qualitative descriptive research based on literature review of scientific books and journals relating to symbolic deixis, persuasive discourse, and learning media. Data are obtained from the texts (terms, jargons, slangs) in the persuasive discourse on road signs. Data collection methods include noting and documentation. Analytical technique is interpretations of symbolic deixis in persuasive discourse on road signs based on forensic linguistic perspective.

\section{RESULTS AND DISCUSSION}

\subsection{Symbolic Deixis}

Deixis is a word that refers to a specific word, phrase or expression in a discourse based on particular context. A word or phrase has a deixical meaning since the context alters. The form of language is deixical if the reference varies depending on the speaker, the situation, and the context so as not to have a fixed referent [7]. An understanding in symbolic deixis relies on the context. When a meaningful implication is implied, it is called symbolic deixis.

The texts on road signs enclose symbolic deixis. The deictic elements of communication process as language expression include demonstrative, person pronoun, time marker and verbs conveyed symbolically and related to situation and condition of speech acts [8]. Symbolic deixis in road signs is related to the culture of society, i.e., ethnicity, economy, religion, politics and lifestyle [9]. The culture related to road signs is the propensity of road users in ignoring them the use of current popular jargons on road signs becomes an effort to change this culture.

\subsection{Persuasive Discourse}

Discourse is a series of events that are communicated by speakers to the speech partner in the form of language. In grammatical hierarchy, discourse is the highest or largest unit [10]. It is the most complete and highest unit above sentences or clauses, which have cohesion and coherence, apparent beginning and end, and conveyed in writing or verbally [11]. Lingual units included in the discourse are clusters of sentences, paragraphs, sections of discourse (article, sub-chapter, chapters, and episode), and intact discourses that show that the basic basis of discourse formation is a sentence [12]. Several concepts can be accommodated in the discourse since it functions as a forum for context or a means to convey the intention of speaker. Discourse is classified into various types based on certain criteria. Among them is the persuasive discourse, which is the object in the present study. It comes from an English word persuasion, which is derived from the verb to persuade [13]. It contains spoken utterances in the form of 
invitations or appeals that direct the speech partner to obey the intention of the speaker. Essentially, it is a set of interrelated propositions and the highest grammatical unit expressed in essays, paragraphs, sentences or words, which deliver a message for the speech partner to follow the invitation and appeal of the speaker.

In public communication, persuasion is defined as propaganda by certain groups or agencies, advertisements in the mass media, leaflets, verbal campaigns, and so forth. Moeliono [14] asserts that persuasion has two meanings, namely: (1) speaker's invitations to others by providing good reasons and prospects in the form of subtle conviction, and (2) essays aimed at proving statements. They frequently use an emotive approach that seeks to arouse and stimulate the emotions of others to change their mind and actions in accordance the intention of the speaker.

Persuasive discourse seeks to persuade or convince others to perform the speaker's invitation. The attempt includes neither compulsion nor violence, hence those whom persuaded will be contended and happy because they carry out a decision voluntarily or free from any threats [15]. Therefore, persuasive discourse requires certain efforts to stimulate other partners to making decisions based on the speaker's purpose. Moreover, speakers will use evidence so that the speech partner can accept the idea and then perform it. It is done to create an agreement that will be achieved based on mutual trust.

Persuasive discourse is used as a means of conveying factual and conceptual information that specifically contains invitations and appeals. It is part of a communication strategy that aims to influence, convince, and invite others to perform speaker's expectation. In fact, it is also utilized on the road signs.

Road signs incorporate informative and persuasive messages. Informative message aims to provide insight and information about traffic regulations to road users. It also aims to influence and change the mindset of road users to comply with traffic regulations [16]. The efficacy of persuasive text on road signs is linked to the informational, emotional, and motivational appeals [17]. The power in the appeal should be supported by explanations and facts to convince road users to comply with traffic regulations so as to realize the order and road safety.

\subsection{Forensic Linguistic-based Learning Media}

The socialization of road signs through to the public through various types of media is required thus the meaning and intentions are disseminated appropriately. The utilization of signs as learning media in schools is a prospective idea. Learning media is a strategic means to optimize the learning process since it is an indicator to achieve the expected outcomes [18]. It is linked to texts as resources in learning discourse hence road signs can be used as learning media. Road signs are a form of rules that employ texts as a communication medium and further, a source of learning for students. The source of learning is any means to help students gain knowledge and concrete experience in the form of role model, tools, community and so forth so as to optimize the expected learning outcomes [19]. Persuasive discourse on road signs as a learning media is a component of the instructional method to achieve optimal outcomes. In the context of language, persuasive discourse analysis on road signs is actual effort to assist students understand the traffic regulations. Texts on road signs contain forensic linguistic perspective. Forensic linguistic studies are language studies related to legal texts which cover various types and forms of text analysis [20]. It discusses the application of linguistic knowledge and techniques to the facts of language contained in legal cases [21]. Forensic linguistics plays a role in understanding and analyzing nonphysical evidence, i.e., verbal, writing or other signs in the legal context [22]. Essentially, forensic linguistic studies can be introduced by using road signs as learning media.

The exploration of persuasive discourse on road signs as learning media aims at cultivating discipline in students. Discipline must be instilled as early as possible since among the main factors of traffic accident is drivers who deliberately or non-deliberately violate traffic regulations. Hence, information about road signs must be introduced to students from an early age to inculcate a positive spirit as road users as they grow up [23]. Moreover, the cultivation of discipline in early age is vital since it is a situation that is created and built through a process of a series of behaviours comprising the values of compliance, obedience, loyalty, order and orderly [24]. These values are an indicator of student's level of adherence to legal regulations in the real interaction in the society.

As road users, students will adapt to the environment, particularly traffic regulations through education gained at school. The characters of being obedient to the law, ethical, empathetic, and thoughtful for the environment are not instant attributes, but requires a long, continuous process and consistency [25]. Therefore, the introduction of the function of road signs must be instilled in children from an early age [18]. It relates to road signs as road equipment in a certain form which contains symbols, letters, numbers, sentences or combinations of them which are used to give warnings, instructions, prohibitions and orders for road users [26]. As learning media, discourse on road signs is a means of introducing regulations to students to have social intelligence in real life. Based on this, the concept of persuasive discourse on road signs with latest jargons as learning media is an endeavour to equip and prepare students to take part in community life.

\subsection{Symbolic Deixis in Persuasive Discourse on Road Signs}

Persuasive discourse on road signs is delivered with concise and up-to-date nuances to attract road users. The texts on road signs are relatively concise since it considers the factors of place and time efficiency, yet they have to embody intact message because it contains symbolic deixis as a persuasive power compiled by utilizing psychological 
aspects. Persuasive power has emotive functions that are used to arouse and stimulate the emotions of road users so that they are interested in reading and obeying traffic rules so as to avoid accidents.

The techniques as the strategy in persuasive discourse are by proposing evidence based on facts that occur in daily life. It uses facts as a basis thus the techniques of argumentation are employed in persuasive discourse [15]. They include rationalization, identification, suggestion, conformity, compensation, displacement, and projection.

Symbolic deixis contained in persuasive discourses on road signs is classified based on the techniques. The classification is related to the characteristics of persuasive speech that uses emotive language with particular words arrangements and special diction/jargon to promote the effectiveness of invitations and appeals. Symbolic deixis analysis in persuasive discourse on road signs is associated with the types of messages, namely warnings, instructions, prohibitions, and commands.

Symbolic deixis analysis based on techniques in persuasive discourse on road signs is described as follows.

\subsubsection{Rationalization}

Rationalization is a persuasive technique of providing limited truth since it is not an absolute truth. Here, the truth only serves to do the basics and facilitate the way so that the desires, attitudes, beliefs, decisions, or actions that have been delivered can be accepted and justified by others.

Rationalization is a process of using reason to provide a justification for a problem that is not a direct cause of the problem [15]. The speaker submits the reasons and the partner accepts the idea. Meanwhile, if it is examined meticulously, the reasons may be inappropriate.

Symbolic deixis in persuasive discourse on road signs by using rationalization technique is elaborated as follows.

\section{(1) Jatuh di aspal tidak seindah jatuh cinta}

Rationalization can be found in persuasive discourse on data (1) which contains warnings aimed at road users. The text "Jatuh di aspal tidak seindah jatuh cinta" (https://bogor.pojoksatu.id/baca/polisi-bogor-bilang-jatuhdi-aspal-tidak-seindah-jatuh-cin ta-ada-apa) means "falling down (onto the road) is not as beautiful as falling in love", using event deixis of jatuh (falling down), spatial deixis of di aspal (on to the road), and situational deixis tidak seindah jatuh cinta (not as beautiful as falling in love).

The analogue of "falling down (onto the road)" and "falling in love" has a justification basis, that is, the pain of falling on a paved road is not as beautiful as the fun when falling in love. Further examination will divulge that the proposed reason is inapt since not all road users have ever felt the sensation.

The persuasive power associated with the use of event deixis of falling down (on to the road) compared to the situational deixis of falling in love. The comparison between the situations has persuasive power to influence road users to obey road signs for preventing any physical injuries. The situational deixis of fall in love is used to attract attention and persuade road users to comply with road signs. The expected action is for road users to obey road signs so there will be no road accidents.

Symbolic deixis refers to event deixis of falling down (onto the road), which can occur as a consequence of not obeying road signs. As a consequence, road users may be physically injured, which is opposed to the feeling of falling in love. The contrast between those feelings is a symbolic deixis that is used to persuade road users to obey the road signs for preventing any road accidents. This warning is implicitly conveyed with a comparison of 'not as beautiful' as referring to physical pain that does not feel as beautiful as someone in love. The contrast between these two opposite feelings is symbolic deixis used to persuade road users for obeying road signs so as not to have an accident.

Figure 1 demonstrates an example of persuasive discourse on road signs with rationalization technique.

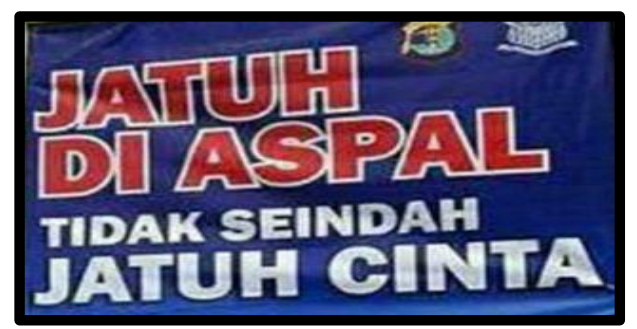

Figure 1. Persuasive discourse with rationalization technique

(Source: https://bogor.pojoksatu.id/)

\section{(2) Matilah engkau di jalan yang lurus, bukan di aspal yang} lurus...

Persuasive discourse on data (2) contains warnings and appeals addressed to road users using rationalization technique. The text of "Matilah engkau di jalan yang lurus, bukan di aspal yang lurus" (https://mjbrigaseli.blogspot.com/2017/09/kumpulantulisan-lucu-dan-menarik-pada .html) means "May you die on a straight path, not on a straight road". It uses persona deixis of engkau (you), event deixis of di jalan (on the path/road), and situation deixis of lurus (straight). The preference of die on a straight path rather than on a straight road is a justification for those to want to die in good condition and not because of fatal accident. It can be accepted by human mind, yet the reason is improper because some roads are straight and some are just not.

Persuasive power relates to the appeal is implicitly conveyed in the word die, which is addressed to the persona pointer you to choose to die on a straight path, not on a straight road. The emotive expression in these words is to recall road users about fatality in order to touch the feelings 
of road users to be careful so as to avoid accidents that may lead to fatality. The expected action of road users is to be careful and obey the traffic rules.

Symbolic deixis refers to the deixis of the place on the path and on the road, which is combined with the situation deixis of straight, meaning the choice between dying in a good way or due to an accident on the highway. Warning and appeal are implicitly conveyed with contradictions not as an option for good things, namely to die on a straight path, naturally or not on road. The message is delivered to road users in order to have awareness to be careful when driving.

\section{(3) Jangan mendahului, Tikungan tajam, Valentino Rossi pernah jatuh di sini}

Persuasive discourse on data (3) contains prohibitions and warnings aimed at road users using rationalization technique. The sign "Jangan mendahului Tikungan tajam, Valentino Rossi pernah jatuh di sini" (https://www.jawapos.com/jpg-today/18/07/2017/ja nganmendahului-di-tikungan-tajam-valentino-rossi-pernah-

jatuh-di-sini), means "Don't overtake, Sharp turn ahead, Valentino Rossi once fell here". It uses the persona deixis of Valentino Rossi, the event deixis of mendahului (overtake) and pernah jatuh (once fell), and spatial deixis of tikungan tajam (sharp turn) and disini (here). The prohibition is marked by the word jangan (don't) aimed at road users so as not to overtake other vehicles because of sharp turns ahead. It has a justification based on the reason Valentino Rossi has once fallen on the spot. Although the proposed reason is not a fact, yet it becomes the justification to attract the attention of road users so that they do not overtake other vehicles at the sharp turn.

The persuasive power is linked to person deixis of Valentino Rossi, event deixis once fell, and place deixis here, which is an implicit reminder that an internationallevel rider once fell on that sharp turn. The use of deixis is persuasive and influences the mind of the road users to be alert and for not overtaking other vehicles, otherwise they may fall down on road just like Valentino Rossi. The expected action is the road user will obey the prohibition as indicated by the word jangan mendahului (don't overtake). Symbolic deixis refers to the persona deixis of Valentino Rossi and event deixis of once fell down which means that outstanding driving skills such as world-class rider do not guarantee that they can survive if they overtake other riders in sharp turns. The symbolic meaning is to warn road users to be extremely careful when passing sharp turns so they do not have an accident.

\subsubsection{Identification}

The identification technique in persuasive discourses seeks to avoid conflict situations and doubts. It requires the speakers to observe and analyze the speech partners and the circumstance. It is done to identify the situation between speaker and speech partner.

To ease the identification process, the same general basis must be created. If the general basis has not been created, the speaker must try to find the broadest general basis. Identification is the key to the success of speakers. If there is a conflict between speaker and speech partner, then the speaker will more easily in identifying the situation based on the characteristics, level of knowledge, and ability of the speech partners [15].

Symbolic deixis in persuasive discourse on road signs using identification technique is described as follows

\section{(4) Awas!!! Tikungan tajam setajam silet}

Persuasive discourse on data (4) contains warnings aimed at road users by using identification technique. The sign "Awas!!! Tikungan tajam setajam silet" (http://manado. tribunnews.com/2016/05/27/foto-rambu-peringat-lalulintas-yang-unik-dan-lucu-awas-tikungan-tajam-setajamsilet) means "Be careful!!! Sharp turns as sharp as razor", with spatial deixis of tikungan tajam (sharp turn) and situational deixis of setajam silet (as sharp as razor). Sharp turn is equated with razor sharpness to indicate the identification of road conditions in the spot. The situational deixis as sharp as razor or setajam silet is quoted from the greetings of entertainment program on a private TV station in Indonesia as an attempt to attract the attention of road users to heed warnings on road signs.

Persuasive power relates to warnings that use the words " $\mathrm{Be}$ careful!!!" and "sharp turn" are intended for road users because they pass a dangerous turn. The warning is persuasive to persuade road users when driving on the sharp turn. The expected action of road users is to pay attention to warnings and obey road signs so that they do not have an accident.

Symbolic deixis refers to the situational deixis as sharp as razor, which is a symbol of the condition of a traffic accident where victim gets severe injuries in which it is alike with the wound by razor sharp objects. It is used to emphasize warnings to be noticed by road users. The symbolic meaning is that road users will be careful not to have an accident with severe injuries and extreme pain. The following Figure 2 is an example of persuasive discourse on road signs with identification technique.

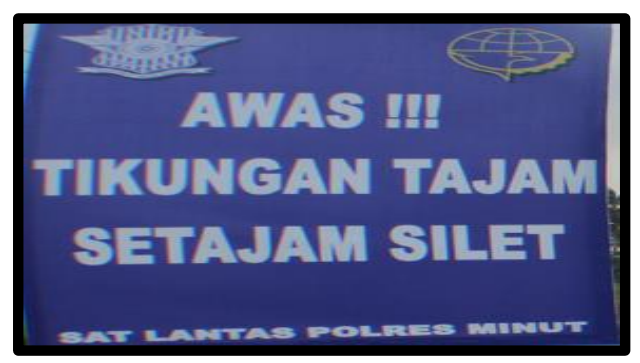

Figure 2. Persuasive discourse with identification technique.

(Source: http://manado.tribunnews.com/) 


\section{(5) Hati-hati tikungan ciluk..ba...!!}

Persuasive discourse on data (5) contains a warning addressed to road users with identification technique. The text "Hati-hati tikungan ciluk..ba..!!!" (http://lampung.tribun news.com/2015/06/22/hati-hatitikungan-tajam-cilukba-di-bakauheni) means "Be careful, a turn ahead, peek-a-boo...!!!” It uses situational deixis be careful and place deixis a turn ahead. The term peek-a-boo in the context of this persuasive discourse is to reinforce an unforeseen turn. This special term is used to attract the attention of road users to be careful ahead.

The persuasive power is also marked by place deixis turn ahead, peek-a-boo..!!! as a warning to road users passing through the spot. A warning is stressed by the word be careful is aimed to road users since there is a dangerous turn ahead. This caution is accompanied by a reminder of a turn ahead, peek-a-boo..!!! is to persuade the mind of the road user to be alert, particularly for not overtaking other vehicles because they will pass an unpredicted turn.

Symbolic deixis is associated with place deixis a turn ahead peek-a-boo...!!!, as a warning to road users to be more watchful since the location is prone to accident. Warning is addressed at road users as an effort to prevent any traffic accidents caused by natural condition of a sharp turn.

(6) Nyawa abang aja gak dijaga...apalagi nyawa adek, mending kita putus

Persuasive discourse on data (6) incorporates warnings aimed at road users using identification technique. The sentence "Nyawa abang aja gak dijaga...apalagi nyawa adek, mending kita putus" (http://tribratanews.pekalongankota.jateng.polri.go.id/?p=1 542) means a man who is careless with his life hence his girlfriend asks for breaking up for good. The sentence uses persona deixis of abang (boyfriend), adek (girlfriend), and kita (us); situational deixis of gak dijaga (being careless); and event deixis of breaking-up. Adek is identified as girlfriend who makes up her mind by asking his boyfriend (abang) to break-up with her because abang is careless as indicated by his bad attitude in driving. The persona deixis "us" shows their relationship as a general basis in the society, which is related to the view that a man must protect a woman.

Persuasive power is demonstrated by persona deixis in the identity of conflicting man and woman in which the man is a careless driver who he endanger their lives. The warning is implicitly conveyed that a boyfriend should protect his girlfriend by being vigilant when driving so as to prevent any accident and for not breaking-up with his girlfriend. This signs contain a persuasive discourse with identification technique by using resemblance of a boyfriend who is a careless driver, which is deemed as an ignorant act towards his life and automatically also towards his girlfriend's. Symbolic deixis is linked to persona deixis, abang and adek who have special relationship. The use of this typical persona deixis is intended so that a man will recall his girlfriend and then be careful when driving. The symbolic meaning of the sign is that road users will comply with traffic regulations to prevent any accidents that can result in casualty.

\subsubsection{Suggestion}

Suggestion is a persuasive technique that is carried out by suggesting or influencing others to accept a certain belief or concept without providing a logical basis of trust. This technique utilizes emotional power gained from the power and obedience to something or someone [15]. In reality, suggestion is usually performed in the forms of words and tone of voice.

Efforts using suggestion techniques must be based on facts to support the accuracy of the text/sign in order to bring the expected outcome. A series of alluring and convincing words, accompanied by a full and authoritative tone of voice can affect someone whom speaker talks to easily.

Symbolic deixis in persuasive discourse on road signs with suggestion technique is elucidated as follows.

(7) Stop penggunaan HP saat berkendara karena Tuhan gak akan tanya "Chating terakhir sama siapa?"

Persuasive discourse on data (7) contains prohibitions and warnings aimed at road users by using suggestion technique. The sign "Stop penggunaan HP saat berkendara karena Tuhan gak akan tanya: "Chating terakhir sama siapa?" (https://satlantasreskediri. files.wordpress.com/2016/12/15390663_12616419738796 899092057747085206780 n1.jpg? $\mathrm{w}=604)$ means "Stop using mobile phone while driving, the Lord won't ask "who you're chatting with." It uses situational deixis "using mobile phone while driving". It urges road users for not using mobile phone while driving because it risks their lives. In the hereafter, it is human's good deeds that will be investigated instead of whom the driver chat with for the last time of his/her life. It has a logical basis of trust because it deals with meeting God after death.

Persuasive power relies on the warning that is conveyed implicitly related to death. It is accentuated by the word "stop", which embodies the suggestion of road users for not using mobile phone while driving. The appeal attempts to raise the awareness of road users and then practice the suggestion of the sign.

Symbolic deixis is linked to the situation, which is to point out those who chatting while driving. The situation and persona intended in the sign is when the road users are driving and using mobile phone at the same time, they are relatively careless and potentially get a fatal accident. The sign mentions "the Lord" is symbolic meaning of the casualty where they will be asked about the good deeds in the world instead of the last activity before their death, which is associated with the use of mobile phone/have a chat with someone, leading them to be careless and to get fatal accident on the road. 
The following figure 3 is an example of persuasive discourse on road signs with suggestion technique.

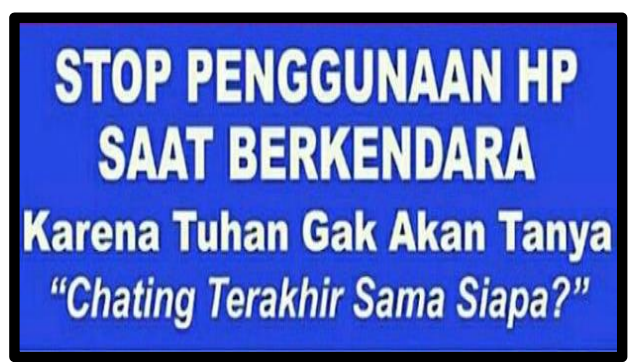

\section{Figure 3. Persuasive discourse with suggestion technique.}

(Source: https://satlantasreskediri.files.wordpress.com/)

(8) Yang orang telfon, SMS, BBM saat berkendara "Izrail, jemput aku yaa..."

Persuasive discourse on data (8) contains prohibitions and warnings aimed at road users by using suggestion technique. The sign "Yang orang telfon, SMS, BBM saat berkendara "Izrail, jemput aku yaa..." (https://mjbrigaseli.blogspot.com/2017/09/kumpu lantulisan-lucu-dan-menarik-pada.html) means those who call, text, or BBM while driving must send it to Izrail or "Angel of Death" to "pick them up". It uses persona deixis of orang and $a k u$ to denote the doers, and situational deixis of call, text, or BBM while driving. Persuasive discourse on data [8] has similarities with data [7] related to fatality caused by traffic accidents. Specifically, it also mentions "Angel of Death" to bring them, which suggests about Izrail who will pick up man before the death does not use a logical basis of trust, because the context in the sentence indicates that the driver is picked up by the Angel of Death.

Persuasive power related to prohibitions is implicitly conveyed using persona deixis orang and $a k u$, and situational deixis of call, text, BBM while driving. It persuades road users for not using mobile phones while driving. The suggestion about Izrail, the Angel of Death is used to suggest the road users to be motivated in obeying traffic regulations, by not calling or texting while driving because it may lead to accident or death. The suggestion is driven by the faith about death that comes at any time. It has become an effective means of expressing warnings and appeals to road users to comply with traffic regulations, namely not using mobile phones while driving.

Symbolic deixis refers to the deixis of events with the inclusion of Izrail, Angel of Death, to remind people of the hereafter. The symbolic meaning is that road users who drive while using mobile phone is close to the presence of Angel of Death. The word pick up shows a request to Angel of Death to revoke the life of driver who want immediate death as a consequence of using mobile phone while driving.
(9) Anda memasuki daerah rawan laka lantas, penunggu jalan di sini senang ngikuti pengemudi yang suka ngebut

Persuasive discourse on data (9) contains warning and appeal for road users with suggestion technique. The sign "Anda memasuki daerah rawan laka lantas, penunggu jalan di sini senang ngikuti pengemudi yang suka ngebut" (https://oto.detik.com/catatan-pengendara-mobil/d-

3804996/hiii-penunggu-jalan-ini-suka-sama-pengendarayang-ngebut), which means the area is a vulnerable prone area, the invisible spirit of this place will be happy to follow a speeding driver. It uses persona deixis of penunggu (the invisible spirit) and pengemudi (driver); spatial deixis of daerah rawan laka lantas (a vulnerable prone area), and event deixis of senang ngikuti (happy to follow) and ngebut (speeding). The myth of spirit who guards the road/area is used as a means to warn and urge drivers for not speeding up their vehicles. Nevertheless, this text ignores a logical basis of trust since it is associated with an invisible realm that cannot be proven truthfully.

Persuasive power is linked to persona deixis that represents the truth about the existence of spirits which is manifested into myths by people as the cause of accidents. The suggestion persuades and influences road users to believe about the existence of spirits as the guardian of the road who will be happy to follow speeding drivers. It is based on the fact that the road is prone to traffic accidents.

Symbolic deixis refers to the persona deixis of the drivers who pass on the road in which the sign reminds them to the calamities lurking due to carelessness in driving. The symbolic meaning is that drivers must be more watchful since the spot is accident prone area. Persona deixis of the invisible spirit as the guard and event deixis of happy to follow are used as eye-catching text for drivers to pay attention on it and to maintain safety by obeying traffic regulations.

\subsubsection{Conformity}

Conformity is a persuasive technique carried out based on intention or actions to make others imitate someone or something. This technique is a mental mechanism to adjust to what someone wants.

Conformity technique is an effort made by someone to show that he is able to behave and act in a position as someone he wants [15]. It includes attempts to adjust or to harmonize in a circumstance that has certain situations and conditions. It is performed so that the desired goal can be attained in a situation without any conflict or resistance from others who are addressed in certain situation.

Symbolic deixis in persuasive discourse on road signs by using conformity technique is described in the analysis below.

(10) Saya adalah jomblo terhormat, bawa surat, dan pakai helm...

Persuasive discourse on data (10) contains commands and appeals addressed to road users with conformity technique. The text "Saya adalah jomblo terhormat, bawa surat, dan 
pakai helm..." (https://mjbrigaseli.blogspot.com/201709/collection-funny-and-inte resting-writing-on.html) implies the driver who is a high-quality jomblo (single), and always brings the vehicle registration certificate and wears helmet. It uses persona deixis of saya (I, the driver), situational deixis of jomblo terhormat (high-quality jomblo), and event deixis of "bawa surat dan pakai helm" (brings certificate and wears helmet). The driver is situated as a high-quality jomblo who acts according to regulations, namely by bringing the vehicle registration certificate and wearing helmet. Command and appeal are marked in the sentence in which it is intended for road users to comply with traffic regulations by carrying a vehicle certificate and wearing a helmet.

Persuasive power is associated with command and appeal using deixis of high-quality jomblo, which is aimed at road users. The situational deixis uses the contemporary term jomblo as a gimmick. The use of situational deixis is to persuade motorists to comply with traffic regulations. The expected action is that road users will be orderly and obedient when riding their motors with a complete certificate and helmet.

Symbolic deixis is related to persona deixis, which is indicated by saya (the driver). Even though the driver's status is still 'single', he is a respectable one since he brings vehicle certificate and wears a helmet while riding his motor. The symbolic meaning is that despite the status of the road users, they are trustworthy as indicated by their capacity to obey traffic regulations.

The following figure 4 is an example of persuasive discourse on road sign with conformity technique.

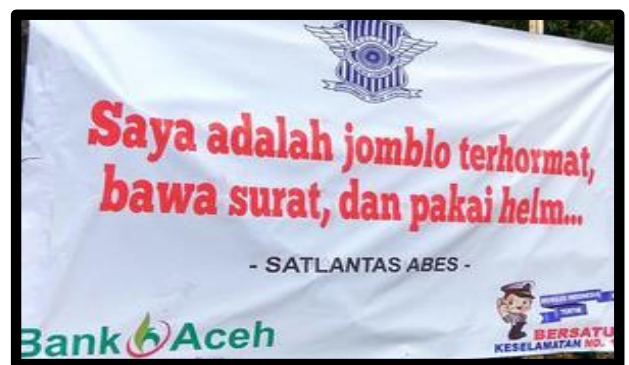

Figure 4. Persuasive discourse with conformity technique.

(Source: https://mjbrigaseli.blogspot.com/)

\section{(11) Jangan ngebut-ngebut ingat anda belum nikah}

The text on the data (11) is a prohibition and an appeal aimed at road users by using conformity technique. The sign of "Jangan ngebut-ngebut ingat anda belum nikah" (https://inet.detik.com/fotoinet/d-4067433/kumpulanpesan-kocak-buat-pemudik-jangan-ngebut/1 /\#photos) is used to recall the road users for not speeding up when driving since they have not gotten married yet. It uses the persona deixis of anda (you), event deixis of ngebut-ngebut (speeding up), and situational deixis of belum nikah (not married). The prohibition is marked with Jangan (don't) that directs the road users to position themselves as being single with an aspiration of being married one day hence they should not be careless on the road.

Symbolic power is contained in the implicit warning for remembering the status of road users. It becomes an effective way to reduce the accident rate on the roads. The expected action is that the road users will slow down their vehicles and drive carefully due to their status of not married yet.

Symbolic deixis is associated with persona deixis of you, situational deixis of speeding up, and situational deixis of not married. Prohibitions and appeals are directed to road users with the status of single in order to be cautious on the roads so as to prevent any accidents. The situation is symbolized by the illustration of an accident that may result in physical disability and affect the marriage plan in which it may be cancelled since the bride abandons the groom. The impact of speeding on the streets is not only a fatal accident, but also on access to future plans of a happy marriage.

\section{(12) Jangan ngebut!!!! Ingat Anda masih bujangan}

Persuasive discourse on data (12) contains prohibitions and warnings aimed at road users by using conformity technique. The sign "Jangan ngebut!!!! Ingat Anda masih bujangan" (https://inet.detik.com/fotoinet/d4067433/kumpulan-pesan-kocak-buat-pemu dik-janganngebut/1/\#photos) means "Don't speed up!! Remember you are still single". It uses persona deixis of anda (you), event deixis of ngebut (speed up), and situational deixis of masih bujangan (still single). Persuasive discourse on data [12] has similarities with data [11], both of them involve the prohibition of speeding up because road users are still single. They are convinced to exhibit their capability to behave and act based on social expectation, which is not speeding up on the road because of their status. The prohibition is emphasized by the command Don't, which directs road users to adjust to the status of still single to suit the expected actions.

Persuasive power embodies in the warning that is implicitly conveyed in remember you are still single hence there is anticipation for not having an accident caused by negligence. It is an effective warning for road users because they are recalled of the single status. The expected action is for not speeding up on the road because of the thoughtfulness of still single.

Symbolic deixis is linked to persona deixis of you, situational deixis of speed up, and conditional deixis of still single. Prohibitions and warnings are aimed at single road users for not speeding up so as to avoid any accident. Situational deixis is symbolized by the image of still single, which implicates a future plan of marriage. The emphasis of remember in the text is a symbolic warning about the condition experienced due to the impact of speeding up, which is a fatal accident and detrimental to future plan. 


\subsubsection{Compensation}

Compensation is an action or an outcome of an effort to find a substitute for an unacceptable thing. It is an attitude or a condition that cannot be maintained in certain situations, so that someone invites others to create a better situation as expected by the community [15].

Persuasive speech can encourage others to take an action or other actions instead of the former ones. The expected action can be fulfilled by showing that a person has the ability that is conveyed by using speech that can convince the speech partner.

Symbolic deixis in persuasive discourse on road signs by using compensation technique is explicated as follows.

\section{(13) Dilarang kecelakaan di sini rumah sakit jauh}

Persuasive discourse on data (13) contains prohibitions and warnings aimed at road users by using compensation technique. The text "Dilarang kecelakaan di sini rumah sakit

(https://iwbspeed.wordpress.com/2014/12/26/dilarang-

kecelakaan-disini-kare na-rumah-sakit-jauh/) implies the warning for road user for not having accident at this area since the hospital is far from here. It contains event deixis of kecelakaan (accident), spatial deixis of disini (here) and rumah sakit (hospital), and situational deixis of jauh (far). Compensation obtained from the accident is a delayed medical treatment due to far distance from hospital. The consequence of accident is the injuries resulted from the accident will not be immediately handled, which cannot be accepted by road users. Prohibition and warning is indicated by the word dilarang (not allowed to) addressed to the road user. The expected action from road users is to be more careful for preventing any accident.

Persuasive power is demonstrated by event deixis of accident and spatial deixis (far from) hospital. Anticipated situation in which the victims of accident cannot immediately obtain medical help due to the location of a remote hospital is used to encourage road users to drive safely. Deixis has persuasive power to raise the awareness of road users to carry out an action or other acts, which is being careful when driving so as to evade an accident.

Symbolic deixis is linked to event deixis and spatial deixis, namely accident at this area and far hospital. The use of event deixis and place deixis has a symbolic meaning, which is the condition of injuries can be fatal due to the postponed treatment, for example permanent disability or even death. Situational deixis is used to provide an insight for road user about traffic rules that must be obeyed while driving.

The following figure 5 below is as an example of persuasive discourse on road sign with compensation technique.

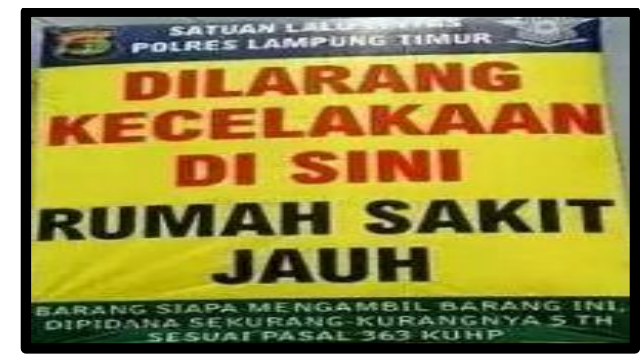

Figure 5. Persuasive discourse with compensation technique.

(Source: https://iwbspeed.wordpress.com/)

(14) Ayah jangan ngebut... bunda tidak mau jadi janda, apalagi ayah cari janda

Stop pelanggaran, Stop kecelakaan, Keselamatan untuk kemanusiaan

Persuasive discourse on data (14) contains prohibitions and appeals aimed at road users by using compensation technique. The sign "Ayah jangan ngebut... bunda tidak mau jadi janda, apalagi ayah cari janda. Stop pelanggaran, Stop kecelakaan, Keselamatan untuk kemanusiaan" (https://inet.detik.com/fotoinet/d-4067433/kumpulanpesan-kocak-buat-pemudik-jangan-ngebut/1/\#photos) expresses a request from bunda (the wife) toward ayah (the husband) for driving on the road safely since she neither wants to be a widow nor allows her husband looks for a widow. It is reinforced by the statement "Stop pelanggaran, Stop kecelakaan, Keselamatan untuk kemanusiaan" (stop violation, stop accident, safety for humanity). It uses persona deixis of ayah/bunda (husband/wife), event deixis of ngebut (speed up), and situational deixis of "tidak mau jadi janda" (does not want to be a widow) by using compensation technique. The prohibition and appeal is reflected in the term janda (widow) as a means of compensation to encourage road users not to speed up in lieu of previous actions. The prohibition on the above discourse is marked by the words jangan (don't) and stop. Persuasive power is associated with humanism as enclosed in the appeal of safety for humanity as the aim of the command of not speeding up. The discourse with persuasive power encourages road users to take an action or other acts as a substitute for speeding up, namely not to violate traffic regulations so that accidents do not occur due to safety for humanity. It is expected that road users will obey traffic rules to promote their safety as well as others.

Symbolic deixis is indicated by the persona deixis of bunda, the wife of the road user who waits at home and prays for the safety of her husband (ayah). The term widow (janda) accompanies the persona deixis of bunda, which is used to attract the attention of road users to remember their wife who will be a widow if her husband has a fatal accident. The symbolic meaning of the discourse is that road users will remember families waiting at home hence they will drive on the road safely.

\section{(15) LGBT: Lagi nyetir Gak Boleh Telefon}

Persuasive discourse on data (15) contains prohibitions and appeals aimed at road users with compensation technique. 
The text "LGBT: Lagi nyetir Gak Boleh Telefon" (http://tribratanews.pekalongankota.jateng.polri.go.id/?p=1 542) means "No Calling While Driving", which uses event deixis of nyetir (driving) and telefon (calling). It actually stands for the abbreviation of lesbian, gay, bisexual, and transgender. It is then altered into a new definition to attract the attention of road users. It embodies prohibition of not being on-call while driving.

The persuasive power in the text is related to the term LGBT, which is recently much discussed by the community, to attract the attention of road users to comply with traffic regulations, particularly regarding the prohibition on using mobile phone while driving. The appeal is implicitly conveyed in the alteration of the term LGBT, which is persuasive to convey the prohibition and appeal to road users for not having phone call while driving. The expected action is that road users comply with regulations by not calling while driving.

The extension of the acronym LGBT is a symbolic deixis to depict the situation marked by the word 'Lagi nyetir (while driving)' as an extension of the letter L, the word 'Gak (No)' for the letter $\mathrm{G}$, the word 'Boleh (may/allowed)' for the letter $\mathrm{B}$, and the word 'telefon (calling)' for the letter $\mathrm{T}$. Event deixis in the text had symbolic meaning that the road users might encounter accident if they do not obey regulations. The prohibition and appeal are conveyed to road users in order to prioritize road safety.

\subsubsection{Displacement}

Displacement is a persuasive technique done by an attempt to replace an intention or thing that faces obstacles with a purpose or other thing which at the same time replaces the original emotion of hatred, or sometimes the emotion of genuine love. Persuasive speech by speakers is done as an effort to convince the speech partner to divert something specific object or destination to a particular goal in order to create better conditions [15].

Symbolic deixis in persuasive discourse on road sign with replacement technique is described as follows.

\section{(16) Jangan kebut-kebutan Bang... Adek belum siap menjanda}

Persuasive discourse on data (16) contains prohibitions and warnings aimed at road users with replacement technique. The text "Jangan kebut-kebutan Bang... Adek belum siap menjanda"

(https://mjbrigaseli.blogspot.com/2017/09/kumpulan-

tulisan-lucu-dan-me narik-pada.html) implies the unhappiness of a wife in being a potential widow as her husband drive carelessly on the road. It uses persona deixis of bang (husband) and adek (wife), event deixis of kebutkebutan (careless driving), and situational deixis of belum siap menjanda (potential widow). The word jangan (don't) emphasizes the prohibition for drivers not to speed up when driving. The persona deixis and event deixis become a displacement process to attain another purpose in the form of attention required by the wife or family (the wife is not ready to be a widow).
The persuasive power of the discourse is linked to person deixis (bang, adek), event deixis (careless driving), and situational deixis (not ready being a widow). The warning is implicitly conveyed to road user (the husband) so as to remember his wife at home - who waits for him and will be extremely sad if her husband dies in an accident. Persona, event and situational deixis are persuasive in moving the hearts of road users to comply with traffic rules to achieve certain goals, namely road safety. The expected action is that they will change the habit of driving carelessly into a safety one.

Symbolic deixis is used to recall the thoughtfulness of road users while driving since there are families waiting at home. The symbolic meaning is that the road users will remember his wife who is not ready to be a widow. This situational deixis is a warning not to drive carelessly hence all drivers will arrive home, safe and sound, to meet their families. The following Figure 6 is an example of persuasive discourse on road sign with displacement technique.

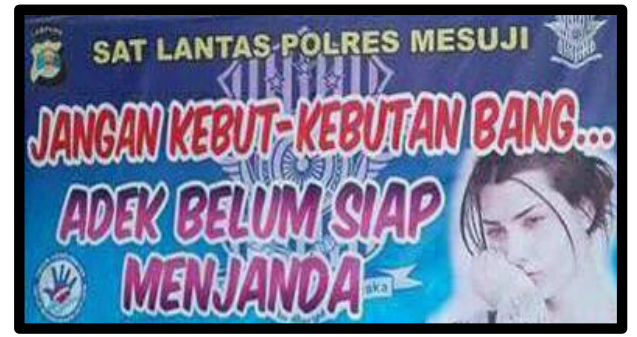

Figure 6. Persuasive discourse with displacement technique.

(Source: https://mjbrigaseli.blogspot.com/)

(17) Bang jangan ngebut, adek masih sayang sama abang, I miss you...

Persuasive discourse on data (17) contains prohibitions and warnings aimed at road users with displacement technique. The text "Bang jangan ngebut, adek masih sayang sama abang, I miss you..." (http://www.tribunnews.com/regional/2016/10/13/lucudan-kreatif-inilah-papan-pesan-keselamatan-lalu-lintasala-polres-sambas) uses persona deixis (abang, adek, I, and you), event deixis (ngebut/speed up), and situational deixis (masih sayang/still love you and I miss you). The word 'jangan (don't)' is an emphasis of a restriction to conduct a particular act of speeding on the streets. Road users are lured by the sentences "still love you, I miss you..." The persona deixis and event deixis are a displacement to achieve another goal in the form of a feeling of being loved by a lover.

Persuasive power is highlighted in the warning implicitly conveyed in the sentence "still loves you, I miss you", hence road users will drive carefully to avoid having an accident. This persuasive suggests road users not to speed up. It is an effective warning for road users not to speed up since there is a lover who still loves and misses them, and truly concerns about them to maintain safety when driving. Symbolic deixis is related to persona deixis (adek and abang), event deixis (ngebut), and situational deixis (masih sayang). Warnings are addressed to road users by persuading them using "Adek masih sayang sama abang (I 
still love you), I miss you", to remind a loved one. The symbolic meaning is that road users are recalled to obey the prohibition and heed warnings for safety, since an accident will break a lover's heart.

\section{(18) Mas ojo ngebut aku isih seneng karo sliramu}

Persuasive discourse on data (18) contains prohibitions and warnings aimed at road users by using displacement technique. In this Javanese text "Mas ojo ngebut aku isih seneng karo sliramu" (https://inet.detik.com/fotoinet/d4067433/kumpulan-pesan-kocak-buat-pemudik-janganngebut/1/\#photos), there are persona deixis of mas (the husband), aku (the wife), and sliramu (you); event deixis (ngebut/speed up); and situational deixis (isih seneng/still in love). Persona and event deixis in "mas ojo ngebut" entail the advice for not speeding up on the road as a displacement to achieve another purpose in the form of a real feeling, which is "aku isih seneng karo sliramu (I'm still in love with you). It has similarities with data [17], namely the prohibition for road users to not speed up conveyed by using persuasion from their lover. It is marked by the word "ojo" (don't) aimed at road users for not driving carelessly.

Persuasive power is indicated by persona deixis of mas, aku and sliramu, and situational deixis of "isih seneng karo sliramu". Persona and situational deixis have persuasive power to persuade the actions of road users so as not to speed up. The warning is conveyed implicitly in the situational deixis of "still in love with you". The expected action from road users is they will slow down their vehicles to prevent any accident.

Symbolic deixis is related to persona deixis and event deixis, namely "mas ojo ngebut" as a persuasion and warning aimed at road users, by using the sentence "aku isih seneng karo sliramu" to remind road users to their loved ones. Deixis in this discourse is symbolically used as a means of persuading road users to drive safely since an accident will bring sadness

\subsubsection{Projection}

Projection is a persuasive technique that is carried out based on a promise to change from what is previously the subject to become an object. The nature or character of a person is no longer recognized as his/hers but instead it is expressed as the nature/character of others. If someone is asked to describe someone they dislike, he/she will try to describe the good things about his/herself [15]. The speaker makes others the scapegoat to cover-up his/her mistake.

Symbolic deixis in persuasive discourse on road sign by using projection technique is elucidated in the analysis below.

(19) Tikungan ini tajam Vallentino Rossi aja bisa jatuh, apalagi ikak

Persuasive discourse on data (19) contains warnings and appeals addressed to road users by using projection technique. The sign "Tikungan ini tajam Vallentino Rossi aja bisa jatuh, apalagi ikak" (http://bangka.tribunnews.com/2017/09/18/tulisanvalentino-ro ssi-aja-bisa-jatuh-apalagi-ikak-bikin-ngakak) uses spatial deixis of tikungan ini (this 'dangerous' turn); persona deixis of Vallentino Rossi and ikak (you); and event deixis of jatuh (fall down). It is used as a warning to road users who do not comply with traffic regulations, and consequently, are projected to fall down (due to sharp turn ahead) as once experienced by Vallentino Rossi. The appeal to road users is to change their driving style into a safety and orderly one. The driver as the subject will turn into an object, in which they are vulnerable to get accident if they are careless, even Vallentino Rossi as one of world champion racers has ever fallen down during the race.

The persuasive power is demonstrated by spatial deixis of tikungan ini, persona deixis of Vallentino Rossi and ikak, and situational deixis of bisa jatuh. The use of deixis in this text is persuasive intended to change behaviour of road user into a more careful driver when passing sharp turns. The desired action of road users is to be careful when passing sharp turns so as not to fall from their vehicles.

Symbolic deixis is related to spatial deixis, persona deixis and situational deixis, namely road users are encouraged not to ride their motors as if they were racers because public roads are not race arena. Warnings and appeals are shown implicitly by the word apalagi (moreover) in the text "Vallentino Rossi aja bisa jatuh, apalagi ikak". They are aimed at road users to be careful because they pass sharp turns. Road users must comply with traffic regulations as their obligation to realize public road safety.

The following figure 7 is an example of persuasive discourse on road sign by using projection technique.

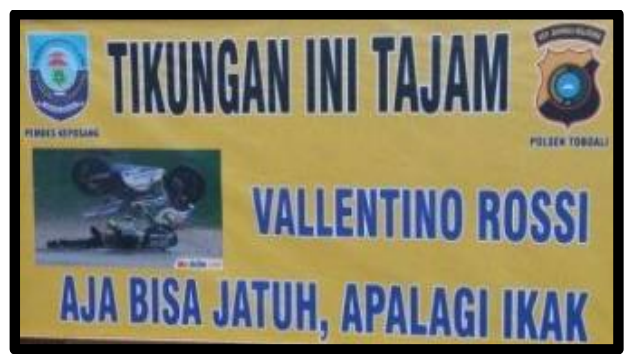

Figure 7. Persuasive discourse in projection technique. (Source: https://bangka.tribunnews.com/)

\section{(20) Rossi aja jatuh bang, apalagi abang, Rossi KW...}

Persuasive discourse on data (20) contains warnings and appeals addressed to road users by using projection technique. The sign "Rossi aja jatuh bang, apalagi abang, Rossi KW..." (https://inet.detik.com/fotoinet/d4067433/kumpulan-pesan-kocak-buat-pemudik-janganngebut/1/\#photos) uses persona deixis of Rossi and bang/abang (to denote spouse), event deixis of jatuh (fall down), and situational deixis of Rossi KW (counterfeit). Deixis used as a technique to change the behaviour of road users who like to speed up like drivers become orderly in driving. Road users who behave as if they were racers (Rossi $K W$ or the counterfeit of Rossi) and as a result, are projected to fall down on the road.

The persuasive power is illustrated by persona deixis of abang or Rossi's counterfeit as the motorist who has possibility to fall down due to negligence. Appeal is 
implicitly conveyed in persona deixis and situational deixis that have persuasive power to change the behaviour of road users, from sloppy into considerate motorist who obeys traffic rules so as to prevent any accident. The expected action from road users is to be careful and orderly so they do not fall or have an accident.

Symbolic deixis is related to persona deixis and event deixis. To evade any possibility of accident, road users must be vigilant while riding the motor. The warning is implicitly conveyed to show a comparison between the real Valentino Rossi and his counterfeit: both have the same possibility to fall down on the road. The symbolic meaning in the warning is that road users are cautious, because even world-class racer like Rossi can make a mistake, let alone motorists who are considered as Rossi $K W$ or fake racers.

(21) Marilah kita patuhi lampu merah Jangan diterobos!!! Yang boleh menerobos lampu merah hanya "kambing"

Persuasive discourse on data (21) contains invitation, prohibition and appeal at the same time, which is addressed to road users using projection technique. The sign "Marilah kita patuhi lampu merah Jangan diterobos!!! Yang boleh menerobos lampu merah hanya kambing" (https://mjbrigaseli.blogspot.com/2017/09/kumpulantulisan-lucu-dan-menarik-pada.html) uses persona deixis of kita (we) and kambing (goat), situational deixis of diterobos

\section{CONCLUSION}

The present study has revealed several points as conclusion. Symbolic deixis in road signs is used to attract road users so as to give more attention on it. Persuasive discourse on road signs is a means to invite road users to obey traffic regulations, particularly to prevent traffic accidents. Symbolic deixis in persuasive discourse on road signs aims at promoting the safety and security of road users. Persuasive discourse on road signs is an effective forensic linguistic-based learning media due to its linkage to traffic regulations.

\section{ACKNOWLEDGMENT}

The writer would like to express his appreciation to those who help in finishing this article. Expression of gratitude is addressed to Rector of Universitas Muhammadiyah Surakarta who gave support for a better academic atmosphere. Thanks are also addressed to the dissertation supervisor for guidance and direction in this study. (ran through), and event deixis of menerobos lampu merah (run through a red light). Deixis is used as a technique to change the behaviour of road users who have previously "run through the red light" to obey traffic lights or otherwise, they will be compared to goat. It projects road users' behaviour, which is goat-like, if they run through the red light. The invitation is signified by the use of the word marilah (let's), while the prohibition by the word jangan (don't).'

Persuasive power is shown by persona deixis of kita (we) and kambing (goat); situational deixis of diterobos, and event deixis of menerobos lampu merah. The deixis is persuasive in encouraging road users for not run through the red light, because only 'goats' that break the red light. The appeal is implicitly conveyed: road users should not run through the red light unless they think and act like 'goats'. The expected action of road users is to comply with traffic regulations by not violating traffic lights.

Symbolic deixis is associated with persona deixis and situational deixis: road users are humans, not goats. If they do not stop at red light, they will be compared to 'goats', in which they will be objectionable for it. Hence, they must comply with traffic regulations by not breaking red lights to avoid accidents for road safety.

\section{REFERENCES}

[1] Jumadi, Makna Istilah dan Bahasa Hukum dalam Konteks Keadilan, Jurisprudentie, vol. 3, no. 1, Juni, 2016, pp. 51-62. DOI:

https://doi.org/10.24252/jurisprudentie.v3i1.3624

[2] Tadkiroatun Musfiroh, Linguistik Forensik dalam Masyarakat Multikultur, Bahasa dan Sastra dalam Perspektif Ekologi dan Multikulturalisme, Jurusan Bahasa dan Sastra Indonesia Fakultas Bahasa dan Seni Universitas Negeri Yogyakarta dan Interlude, Yogyakarta, 2014. DOI:

http://fbs.uny.ac.id/berita/buku-terbaru-bahasa-dansastra-dalam-perspektif-ekologi-danmultikulturalisme.html

[3] Yulia Agustin, Hilda Hilaliyah, and Syarifudin Yunus, Penggunaan Bahasa Iklan pada Papan Reklame (Studi Survei Sepanjang Kampung Rambutan sampai dengan Lebak Bulus), Jurnal Pujangga vol. 1, no. 2, Desember, 2015, pp. 54-65. DOI:

http://journal.unas.ac.id/pujangga/article/view/318

[4] Maria Magdalena Sinta Wardani, Bahasa Indonesia dalam Wacana Persuasif Imbauan Publik, Buku Kumpulan Makalah Konggres Internasional Masyarakat Linguistik Indonesia (KIMLI) Menggali Kekayaan Bahasa Nusantara, Denpasar, Indonesia, 2016, Agustus 24-27. DOI:

https://www.researchgate.net/publication/327261200_B AHASA_INDONESIA_DALAM_WACANA_PERSU ASIF_IMBAUAN_PUBLIK 
[5] Sarma Panggabean and Febrika Dwi Lestari, Implementasi Apraisal dalam Evaluasi Bahasa: Sebuah Ancangan Wacana Forensik (Studi Kasus pada Artikel Mahasiswa Program Studi Pendidikan Bahasa dan Sastra Indonesia FKIP Universitas HKBP Nommensen), Melanesia: Jurnal Ilmiah Kajian Bahasa dan Sastra, vol. 1, no. 2, Februari, 2017, pp. 81-89. DOI: https://dx.doi.org/10.30862/jm.v2i1.788

[6] Awalludin, Efektivitas Model Decision Making dalam Pembelajaran Menulis Paragraf Persuasif Siswa Kelas X SMK Trisakti Baturaja, Jurnal Bindo Sastra, vol. 2, no. 1, 2018, pp. 159-167. DOI: https://doi.org/10.32502/jbs.v2i1.923

[7] Abdul Chaer, "Linguistik Umum", Rineka Cipta, Jakarta, 2007.

[8] Nurul Shahida Jamil and Maslida Yusof, Analisis Deiksis Dialek Kedah, Gema Online Journal of Language Studies, vol. 15, no. 1, Februari, 2015, pp. 163-187. DOI:

http://ejournal.ukm.my/gema/article/view/6525/3239

[9] Ditha Prasanti and Sri Seti Indriani, Pemaknaan Simbol dalam Komunitas 'Brotherhood' (Konstruksi Makna Simbol sebagai Identitas Diri dalam Komunitas 'Brotherhood' di Bandung), Semiotika, vol. 10, no. 1, Juni, 2016, pp. 1-24. DOI:

https://journal.ubm.ac.id/index.php/semiotika/article/vie $\mathrm{w} / 25 / 22$

[10] Harimurti Kridalaksana, Kamus Linguistik, Gramedia Pustaka Utama, Jakarta, 2008.

[11] Henry Guntur Tarigan, Pengajaran Wacana, Angkasa, Bandung, 2009.

[12] Praptomo Baryadi Isodarus, Wacana Prosedural Perihal Pelaksanaan Tugas Perawat, Jurnal Ilmiah Kebudayaan Sintesis vol. 10, no. 1, Maret, 2016, pp. 47-55. DOI:

http://download.garuda.ristekdikti.go.id/article.php?arti cle $=1707179 \& \mathrm{val}=10046 \&$ title $=$ WACANA $\% 20$ PROS EDURAL\%20PERIHAL\%20PELAKSANAAN\%20TU GAS\%20PERAWAT

[13] Marwoto, Suyatmi, and Suyitno, Komposisi Praktis, Hanindita, Yogyakarta, 1987.

[14] Anton M. Moeliono, Kamus Besar Bahasa Indonesia, Depdikbud, Jakarta, 2003.

[15] Gorys Keraf, Argumentasi dan Narasi, Gramedia, Jakarta, 2013.

[16] Noor Aini, Strategi Komunikasi Satlantas Polres Penajam Paser Utara dalam Mensosialisasikan Tertib Lalu Lintas untuk Menekan Tingkat Kecelakaan Tahun 2015, eJournal Ilmu Komunikasi vol. 4, no. 3, 2016, pp
280-289. DOI: https://ejournal.ilkom.fisipunmul.ac.id/site/wpcontent/uploads/2016/08/Jurnal\%20Online\%20(08-2216-08-16-54).pdf

[17] Dwi Budiyanto, Aspek Persuasif dalam Bahasa Iklan Partai Politik, Litera, vol. 13, no. 1, April, 2014, pp. 43-52. DOI: https://doi.org/10.21831/1tr.v13i1.1902

[18] Eni Irfiani, Aplikasi Pengenalan Rambu Lalu Lintas untuk Anak Usia Dini Berbasis Multimedia Interaktif, Konferensi Nasional Ilmu Sosial \& Teknologi (KNiST), Indonesia, 2013, Maret 30. DOI: https://seminar.bsi.ac.id/knist/index.php/UnivBSI/articl e/view/270

[19] Izhar, Konteks Pragmatik dalam Proses Pembelajaran Bahasa di Kurikulum 2013, Jurnal Kreasi, vol. XV, no. 1, Februari, 2015, pp. 15-27. DOI: https://studylibid.com/doc/423956/konteks-pragmatikdalam-proses-pembelajaran-bahasa-di

[20] Lilis Hartini, "Penerapan Fonetik Akustik dan Teori Grice pada Rekaman Penyadapan Telepon sebagai Alat Bukti Hukum: Kajian Linguistik Forensik terhadap Percakapan Antara Artalyta Suryani dengan Jaksa Urip Tri Gunawan”, Jurnal Wawasan Hukum, vol. 23, no. 2, September, 2010, pp. 223-240. DOI: http://dx.doi.org/10.25072/jwy.v23i2.14

[21] John Olsson, Forensic Linguistics, Continuum, New York, 2008.

[22] Yasraf Amir Piliang, Forensik dalam Persfektif Budaya: Sebuah Tantangan Bagi Semiotika, Jurnal Sosioteknologi vol. no. 12, Agustus, 2013, pp. 367-376. DOI:

http://dx.doi.org/10.5614\%2Fsostek.itbj.\%202013.12.2 9.1

[23] Riyadi Purwanto, Membangun Media Pembelajaran Rambu Lalu Lintas dengan Animasi Sebagai Metode Pembelajaran Sejak Usia Dini Studi Kasus TK Aisyah Brebes, Jurnal Inovtek Polbeng - Seri Informatika vol. 2, no. 2, November, 2017, pp. 73-83. DOI:

https://www.researchgate.net/deref/http\%3A\%2F\%2Fd x.doi.org\%2F10.35314\%2Fisi.v2i2.193" It "_blank

[24] Fitria Wulandari, Pemahaman Pelajar tentang Disiplin Berlalu Lintas (Studi di SMK Kesehatan Samarinda), eJournal Sosiatri-Sosiologi, vol. 3, no. 3, 2015, pp. 52-64. DOI: https://doi.org/10.21831/jpvo.v1i2.24029

[25] I Wayan Suweda, Pentingnya Pengembangan Zona Selamat Sekolah Demi Keselamatan Bersama di Jalan Raya (Suatu Tinjauan Pustaka), Jurnal Ilmiah Teknik 
Sipil vol. 13, no. 1, Januari, 2009, pp. 1-12. DOI:

https://ojs.unud.ac.id/index.php/jits/article/view/3516

[26] Menteri Perhubungan Republik Indonesia,

Peraturan Menteri Perhubungan Nomor 13 Tahun 2014

Tentang Rambu Lalu Lintas, Kementerian

Perhubungan, Jakarta, 2014. 